Y. K. Hamidi ${ }^{1,2}$ *, M. C. Altan ${ }^{1}$

${ }^{1}$ School of Aerospace and Mechanical Engineering, University of Oklahoma, Norman, OK, USA

${ }^{2}$ Ecole Nationale Supérieure des Mines de Rabat, Rabat, Morocco

\title{
Process Induced Defects in Liquid Molding Processes of Composites
}

Liquid Composite Molding (LCM) processes are cost efficient manufacturing alternatives to traditional autoclave technology for producing near-net shape structural composite parts. However, process induced defects often limit wider usage of LCM in structural applications. Thorough knowledge of these defects, as well as their formation mechanisms and prevention techniques is essential in developing improved LCM processes. In this article, process induced defects in liquid molding processes of composites, categorized into preform, flow induced and cure induced defects, are reviewed. Preform defects are further presented as fiber misalignment and fiber undulation (waviness and wrinkling). The respective causes, detrimental effects, and possible prevention methods of these defects are presented. Thereafter, flow induced defects are classified as voids and dry spots. Dry spot formation mechanisms in LCM processes and available prevention techniques are summarized. In addition, void formation mechanisms, adverse effects on composite properties, and removal techniques are presented. Cure induced defects include microcracks, void growth and geometrical distortions (warpage and spring-in). Each of these defects are discussed along with their underlying causes as well as their control and reduction schemes.

\section{Introduction}

Advanced composites have been traditionally utilized as structural parts where high performance is essential at reduced weight, such as aeronautical, aerospace and defense applications (Carlone and Palazzo, 2015; Costa et al., 2006; MuricNesic et al., 2009; Villière et al., 2015). Following the success of such applications, there has been increased interest in using advanced composites for higher production rate and cost sensitive fields such as automotive, marine and wind energy applications, among others (Altmann et al., 2016; Gourichon et al., 2006; Kedari et al., 2011; Wang et al., 2013). In this context, significant attention has been placed on developing lower-cost, higher performance Liquid Composite Molding (LCM) processes that can produce medium to large composites structures.

\footnotetext{
* Mail address: Youssef K. Hamidi, Ecole Nationale Supérieure des Mines de Rabat, Avenue Hadj Ahmed Cherkaoui, B.P. 753 Agdal, Rabat, Morocco

E-mail: hamidi@ou.edu
}

In addition to being less expensive, LCM processes offer major advantages over autoclave processing which primarily uses prepregs or wet lay-ups. These advantages include high attainable fiber volume fraction, ability to produce complex nearnet-shape parts, relatively short cycle times, and low labor requirements (Gourichon et al., 2006; Kaynak et al., 2008; Yang et al., 2010).

During initial development of LCM processes, their limited application in the production of structural components was associated to the low degree of process automation, thus resulting in large variations of material properties and low productivity (Kaynak et al., 2008; Yang et al., 2010). Recently, significant developments of robotized preform placement allowed LCM processes to be more competitive (Fedulov et al., 2015; Heuer et al., 2015; Lukaszewicz et al., 2012). Currently, LCM variants, such as Resin Transfer Molding (RTM) and Vacuum Assisted Resin Transfer Molding (VARTM), are increasingly used to fabricate structural parts in a wide variety of industrial applications.

A typical LCM process can be divided into several steps. First, the dry fiber reinforcement, often referred to as preform, is cut to size and placed into a mold cavity. After the mold is closed, the reacting resin is either injected under positive pressure or pulled in the mold cavity due to the applied vacuum. In both cases, the resin impregnates the dry fibrous network by displacing the air initially present in the preform pores. After the preform is impregnated, matrix crosslinking and complete cure are achieved within minutes or hours, depending on the cure kinetics of the resin and the temperature profile used. During LCM, various process parameters affect the quality of resulting composite parts, such as fiber volume fraction, resin injection pressure/applied vacuum level, fiber architecture, location of injection and ventilation gates, resin viscosity, and molding temperature (Gourichon et al., 2006; Kaynak et al., 2008; Yang et al., 2010).

One remaining key challenge that limits a wider usage of LCM is the presence of process induced defects. LCM processes, like any other composite manufacturing technique, are associated with a number of specific defects. LCM induced defects can be grouped into three main types: (i) preform defects, (ii) flow induced defects, and (iii) cure induced defects. Preform defects often refer to the deformation of fiber tows and preforms that are supposed to be spatially uniform, straight and properly aligned in the composite. On the other hand, flow induced defects are flaws caused by the resin flow during im- 


\section{References}

Aaboud, B., Saouab A. and Nawab, Y., "Simulation of Air Bubble's Creation, Compression, and Transport Phenomena in Resin Transfer Moulding", J. Comp. Mat., 1-13 (2017) DOI: $10.1177 / 0021998317697481$

Abraham, D. and Mcllhagger, R., "Investigations into Various Methods of Liquid Injection to Achieve Mouldings with Minimum Void Contents and Full Wet Out", Comp. A, 29, 533-539 (1998) DOI: 10.1016/S1359835X(97)00124-3

Acquah, C., Datskov, I., Mawardi, A., Zhang, F., Achenie, L. E. K., Pitchumani, R. and Santos, E., "Optimization Under Uncertainty of a Composite Fabrication Process Using a Deterministic One-Stage Approach", Comp. \& Chem. Engr., $\quad 30, \quad 947-960 \quad$ (2006) DOI:10.1016/j.compchemeng.2005.12.015

Adams, D. O. and Bell, S. J., "Compression Strength Reductions in Composite Laminates Due to MultipleLayer Waviness", Comp. Sci. Tech., 53, 207-12 (1995) DOI:10.1016/0266-3538(95)00020-8

Adams, D. O. and Hyer, M. W., "Effect of Layer Waviness on the Compression Fatigue Performance of Thermoplastic Composite Laminates", Fatigue, 16, 385-91 (1994) DOI:10.1016/0142-1123(94)90450-2

Afendi, M., Banks, W. M. and Kirkwood D. "Bubble Free Resin for Infusion Process", Comp. A, 36, 739-746 (2005) DOI:10.1016/j.compositesa.2004.10.030

Aktas, L., Hamidi, Y. K. and Altan, M. C., "Effect of Moisture on the Mechanical Properties of Resin Transfer Molded Composites. Part I: Absorption”, J. Mat. Proc. \& Manuf. Sci., 10, 239-254 (2002) DOI: $10.1177 / 1062065602010004005$

Aktas, L., Hamidi, Y. K. and Altan, M. C., "Effect of Moisture on the Mechanical Properties of Resin Transfer Molded Composites. Part II: Desorption". J. Mat. Proc. \& Manuf. Sci., 10, 255-268 (2002) DOI: $10.1177 / 1062065602010004005$

Alexandric, D., Carlone, P. and Cirovic, V., "Optimization of the Temperature-Time Curve for the Curing Processof Thermoset Matrix Composites", Appl. Comp. Mater., 23, 1047-1063 (2016) DOI:10.1007/s10443-016-9499-y

Allison B. D. and Evans J. L., "Effect of Fiber Waviness on the Bending Behavior of S-Glass/Epoxy Composites", Mat. \& Design, 36, 316-322 (2012) DOI:10.1016/j.matdes.2011.11.012

Altmann, A., Taubert, R., Mandel, U., Hinterhoelzl, R. and Drechsler, K., "A Continuum Damage Model to Predict the Influence of Ply Waviness on Stiffness and Strength in Ultra-Thick Unidirectional Fiber-Reinforced Plastics", J. Comp. Mat., 50, 2739-2755 (2016) DOI: $10.1177 / 0021998315612536$

Altmann, A., Gesell, P. and Drechsler, K., "Strength Prediction of Ply Waviness in Composite Materials Considering Matrix Dominated Effects", Comp. Struct., 127,51-59 (2015) DOI:10.1016/j.compstruct.2015.02.024

Anders, M., Lo, J., Centea, T. and Nutt, S. "Development of a Process Window for Minimizing Volatile-Induced Surface Porosity in the Resin Transfer Molding of a Benzoxazine/Epoxy Blend", SAMPE J., 52, 44-55 (2016)

Bafwick, S. C. and Papathanasiou, T. D., "Identification of Fiber Misalignment in Continuous Fiber Composites", Polym. Comp., 24, 475-786 (2003) DOI:10.1002/pc.10046

Baran, I., Cinar, K., Ersoy, N., Akkerman, R. and, Hattel, J. H., "A Review on the Mechanical Modeling of Composite Manufacturing Processes", Arch. Comput. Meth. Engr., 24, 365-395 (2017) DOI:10.1007/s11831-016-9167-2
Barraza, H. J., Aktas, L., Hamidi, Y. K., Long Jr., J., O'Rear, E. A. and Altan, M. C., "Moisture Absorption and WetAdhesion Properties of Resin Transfer Molded (RTM) Composites Containing Elastomer-Coated Glass Fibers", J. Adh. Sci. \& Tech., 17, 217-233 (2003) DOI:10.1163/156856103762302014

Barraza, H. J., Hamidi, Y. K., Aktas, L., O'Rear, E. A. and Altan, M. C., "Porosity Reduction in the High-Speed Processing of Glass-Fiber Composites by Resin Transfer Molding (RTM)", J. Comp. Mat., 38, 195-226 (2004) DOI: $10.1177 / 0021998304038649$

Bednarcyk, B. A., Aboudi, J. and Arnold, S. M., "The Effect of General Statistical Fiber Misalignment on Predicted Damage Initiation in Composites", Comp. B, 66, 97-108 (2014) DOI:10.1016/j.compositesb.2014.04.014

Bloom, L. D., Wang J. and Potter, K. D., "Damage Progression and Defect Sensitivity: An Experimental Study of Representative Wrinkles in Tension", Comp. B, 45, 449-458 DOI:10.1016/j.compositesb.2012.05.021

Bogetti, T. A. and Gillespe, J. W., "Two-Dimensional Cure Simulation of Thick Thermosetting Composites", J. Comp. Mat., 25, 239-273 (1991) DOI: $10.1177 / 002199839102500302$

Brauner, C., Frerich, T. and Herrmann A. S., "CureDependent Thermomechanical Modelling of the Stress Relaxation Behaviour of Composite Materials During Manufacturing”, J. Comp. Mat., 51, 877-898 (2017) DOI: $10.1177 / 0021998316656924$

Carlone, P. and Palazzo, G. S., "Unsaturated and Saturated Flow Front Tracking in Liquid Composite Molding Processes Using Dielectric Sensors", Appl. Comp. Mat., 22, 543-557 (2015) DOI:10.1007/s10443-014-9422-3

Costa M. L., Rezende, M. C. and de Almeida, S. F. M., "Effect of Void Content on the Moisture Absorption in Polymeric Composites", Polym. Plast. Tech. \& Eng., 45, 691-698 (2006) DOI:10.1080/03602550600609549

Choi, J. H. and Dharan, C. K. H., "Mold Fill Time and Void Reduction in Resin Transfer Molding Achieved by Articulated Tooling", J. Comp. Mat., 36, 2267-2285 (2002) DOI: $10.1177 / 0021998302036019536$

Chowdhury, K. A., Talreja, R. and Benzerga, A. A., "Effects of Manufacturing-Induced Voids on Local Failure in Polymer-Based Composites", J. Eng. Mat. \& Tech., 130, 021010:1-9. (2008) DOI:10.1115/1.2841529

Cichocki Jr, F. R. and Thomason, J. L., "Thermoelastic Anisotropy of a Natural Fiber". Comp. Sci. Tech., 62, 669678 (2002) DOI:10.1016/S0266-3538(02)00011-8

Dai S., Cunningham, P.R., Marshall, S., Silva, C., "Influence of Fibre Architecture on the Tensile, Compressive and Flexural Behaviour of 3D Woven Composites", Comp. A, 69, 195-207

(2015) DOI:10.1016/j.compositesa.2014.11.012

Demirci, H. H., Coulter, J. P. and Guceri, S. I., "A numerical and Experimental Investigation of Neural Network-Based Intelligent Control of Molding Processes", J. Manuf. Sci. \& Eng., 119, 88-94 (1997) DOI:10.1115/1.2836559

Demirci, H. H. and Coulter, J. P., "Control of Flow Progression During Molding Processes", J. Mat. Process. \& Manuf. Sci., 3, 409-425 (1995)

DeValve, C. and Pitchumani, R., "Simulation of Void Formation in Liquid Composite Molding Processes", $\begin{array}{llll}\text { Comp. } & \text { A, } & \text { 51, } & 22-32\end{array}$ DOI:10.1016/j.compositesa.2013.03.016 
Do, T. T. and Lee, D. J. "Analysis of Tensile Properties for Composites with Wrinkled Fabric”, J. Mech. Sci. \& Tech., 24, 471-479 (2010) DOI:10.1007/s12206-009-1207-5

Dodwell, T. J., Butler, R. and Hunt, G. W., “Out-of-Plane Ply Wrinkling Defects During Consolidation Over an External Radius", Comp. Sci. \& Tech., 105, 151-159 (2014) DOI:10.1016/j.compscitech.2014.10.007

Dong, C., "Experimental Investigation on The Fiber Preform Deformation Due to Mold Closure for Composites Processing”, Int. J. Adv. Manuf. Tech., 71, 585-591 (2014) DOI:10.1007/s00170-013-5517-5

Dong, C., Zhang, C., Liang, Z. and Wang, B., “Assembly Dimensional Variation Modelling and Optimization for the Resin Transfer Moulding Process", Modelling Simul. Mater. Sci. Eng., 12, 221-237 (2004) DOI:10.1088/09650393/12/3/S11

El-Hajjar R. F. and Petersen D. R., "Gaussian Function Characterization of Unnotched Tension Behavior in a Carbon/Epoxy Composite Containing Localized Fiber Waviness", Comp. Struct., 93, 2400-2408 (2011) DOI:10.1016/j.compstruct.2011.03.029

Fedulov, B. N., Antonov, F. K., Safonov, A. A., Ushakov, A. E. and Lomov, S. V., "Influence of Fibre Misalignment and Voids on Composite Laminate Strength", J. Comp. Mat., 49, 2887-2896 (2015) DOI:10.1177/0021998314557533

Gan, J.M., Bickerton, S. and Battley, M., "Quantifying Variability within Glass Fibre Reinforcements Using an Automated Optical Method", Comp. A, 43, 1169-1176 (2012) DOI:10.1016/j.compositesa.2012.03.024

Gangloff, J. J. Jr., Daniel, C. and Advani, S. G., "A Model of Two-Phase Resin and Void Flow During Composites Processing", Int. J. Multiph. Flow, 65, 51-60 (2014) DOI:10.1016/j.ijmultiphaseflow.2014.05.015

Garnich, M. R. and Karami G., "Finite Element Micromechanics for Stiffness and Strength of Wavy Fiber Composites", J. Comp. Mater., 38, 273-292 (2004) DOI: $10.1177 / 0021998304039270$

Gascón, L., García, J. A., LeBel, F., Ruiz, E. and Trochu, F., "Numerical Prediction of Saturation in Dual Scale Fibrous Reinforcements During Liquid Composite Molding", Comp. A, 77, 275-284 (2015) DOI:10.1016/j.compositesa.2015.05.019

Gereke, T., Döbrich, O., Hübner, M. and Cherif, C., "Experimental and Computational Composite Textile Reinforcement Forming: A Review", Comp. A, 46, 1-10 (2013) DOI:10.1016/j.compositesa.2012.10.004

Ghiorse, S. R., "Effect of Void Content on the Mechanical Properties of carbon/Epoxy Laminates", SAMPE Quart., 24, 54-59 (1992)

Golestanian, H. and El-Gizawy, A. S., "Modeling of Process Induced Residual Stresses in Resin Transfer Molded Composites with Woven Fiber Mats, J. Comp. Mat., 35, 1513-1528 (2001) DOI:10.1106/VW5C-GN89-UXKRWFKT

Goodwin, A. A., Howe, C. A. and Paton R. J., "The Role of Voids in Reducing the Interlaminar shear Strength in RTM Laminates", Proceedings of Int. Conf. Comp. Mat., Australian Compos. Struct. Soc., IV, 11-19 (1997)

Gourichon, B., Binetruy, C. and Krawczak, P., "A new Numerical Procedure to Predict Dynamic Void Content in Liquid Composite Molding", Comp. A, 37, 1961-1969 (2006) DOI:10.1016/j.compositesa.2005.12.017

Gourichon, B., Deleglise, M., Binetruy, C. and Krawczak, P., "Dynamic Void Content Prediction During Radial Injection in Liquid Composite Molding. Comp. A, 39, 4655 (2008) DOI:10.1016/j.compositesa.2007.09.008

Guloglu, G. E., Hamidi Y. K. and Altan, M. C., "Fast Recovery of Non-Fickian Moisture Absorption Parameters for Polymers and Polymer Composites", Polym. Engr. \& Sci., (2016) DOI: 10.1002/pen.24469

Haider, M., Hubert, P. and Lessard, L., "An Experimental Investigation of Class A Surface Finish of Composites Made by the Resin Transfer Molding Process". Comp. Sci. \& Technol., 67, 3176-3186 (2007) DOI:10.1016/j.compscitech.2007.04.010

Hamidi, Y. K., Aktas, L. and Altan, M. C., "Formation of Microscopic Voids in Resin Transfer Molded Composites”, J. Eng. Mat. \& Techn., 126, 420-426 (2004) DOI:10.1115/1.1789958

Hamidi, Y. K., Aktas, L. and Altan, M. C., "Effect of Packing on Void Morphology in Resin Transfer Molded EGlass/Epoxy Composites", Polym. Comp., 26, 614-627. (2005) DOI:10.1002/pc.20132

Hamidi, Y. K., Aktas, L. and Altan, M. C., "ThreeDimensional Features of Void Morphology in Resin Transfer Molded Composites", Comp. Sci. \& Tech., 65, 1306-1320

(2005)

DOI:10.1016/j.compscitech.2005.01.001

Hamidi Y. K. and Altan, M. C., "Chapter 207: Process Induced Defects in Resin Transfer Molded Composites", in Comprehensive Composite Materials, Tyler, J. (Ed.), Elsevier Publisher, 1-12 (2017)

Hamidi, Y. K. and Altan, M. C., "Spatial variation of void morphology in resin transfer molded E-glass/epoxy composites", J. Mat. Sci. lett., 22, 1813-1816 (2003) DOI:10.1023/B:JMSL.0000005428.88229.5b

Hamidi, Y. K., Dharmavaram, S., Aktas, L. and Altan, M. C., "Effect of Fiber Content on Void Morphology in Resin Transfer Molded E-Glass/Epoxy Composites", J. Eng. Mat. \& Tech., 131, 021014:1-11 (2009) DOI: $10.1115 / 1.3030944$

Han, K. and Lee, L. J., "Dry Spot Formation and Changes in Liquid Composites Molding: I-Experiments", J. Comp. Mat., 30, 1458-1474 (1996) DOI: $10.1177 / 002199839603001303$

Hagstrand, P.-O., Bonjour, F. and Manson, J.-A. E., "The influence of Void Content on the Structural Flexural Performance of Unidirectional Glass Fibre Reinforced Polypropylene Composites", Comp. A, 36, 705-714 (2005) DOI:10.1016/j.compositesa.2004.03.007

Harper, B. D., Staab, G. H., and Chen, R. S., "A Note on the Effects of Voids Upon the Hygral and Mechanical Properties of AS4/3502 Graphite/Epoxy", J. Comp. Mat., 21, 280-289 (1987) DOI:10.1177/002199838702100306

Heuer, H., Schulze, M., Pooch, M., Gabler, S., Nocke, A., Bardl, G., Cherif, C., Klein, M., Kupke, R., Vetter, R., Lenz, F., Kliem, M., Bülow, C., Goyvaerts, J., Mayer, T. and Petrenz, S., "Review on Quality Assurance Along the CFRP Value Chain - Nondestructive Testing of Fabrics, Preforms and CFRP by HF Radio Wave Techniques", Comp. B, 77, 494-501 (2015) DOI:10.1016/j.compositesb.2015.03.022

Hörrmann, S., Adumitroaie, A., Viechtbauer, C. and Schagerl, M., "The Effect of Fiber Waviness on the Fatigue Life of CFRP Materials", Int. J. Fatigue, 90, 139-147 (2016) DOI:10.1016/j.ijfatigue.2016.04.029

Hsiao, H. M. and Daniel I. M., "Effect of Fiber Waviness on Stiffness and Strength Reduction of Unidirectional Composites Under Compressive Loading", Comp. Sci. \& Tech., 56, 581-93 (1996) DOI:10.1016/02663538(96)00045-0

Hsiao, K. -T., Devillard, M. and Advani, S. G., "Simulation Based Flow Distribution Network Optimization for Vacuum Assisted Resin Transfer Moulding Process", 
Model. \& Simul. Mat. Sci. \& Eng., 12, 175-190 (2004) DOI:10.1088/0965-0393/12/3/S08

Hsiao, K. -T. and Gangireddy, S., "Investigation on the Spring-In Phenomenon of Carbon Nanofiber-Glass Fiber/Polyester Composites Manufactured with Vacuum Assisted Resin Transfer Molding", Comp. A, 39, 834-842 (2008) DOI:10.1016/j.compositesa.2008.01.015

Huang, H. and Talreja, R., "Effects of Void Geometry on Elastic Properties of Unidirectional fiber Reinforced Composites", Comp. Sci. \& Tech., 65, 1964-1981 (2005) DOI:10.1016/j.compscitech.2005.02.019

Ikegawa, N., Hamada, H., and Maekawa, Z., "Effect of Compression Process on Void Behavior in Structural Resin Transfer Molding", Polym. Eng. \& Sci., 36, 953-962 (1996) DOI:10.1002/pen.10483

Jiang, S., Zhang, C. and Wang, B., "Optimum Arrangement of Gate and Vent Locations for RTM Process Design Using a Mesh Distance-Based Approach", Comp. A, 33, 471-481 (2002) DOI:10.1016/S1359-835X(01)00146-4

Johnson, R. J. and Pitchumani, R., "Simulation of Active Flow Control Based on Localized Preform Heating in a VARTM Process", Comp. A, 37, 1815-1830 (2006) DOI:10.1016/j.compositesa.2005.09.007

Judd, N. C. W. and Wright, W. W., "Voids and Their Effects on the Mechanical Properties of Composites: An Appraisal", SAMPE J., 14, 10-14 (1978)

Jumahat, A., Soutis, C., Jones, F. R. and Hodzic, A., "Fracture Mechanisms and Failure Analysis of Carbon Fibre/Toughened Epoxy Composites Subjected to Compressive Loading", Comp. Struct., 92, 295-305 (2010) DOI:10.1016/j.compstruct.2009.08.010

Kang, M. K., Lee, W. I. and Hahn, H. T., "Formation of Microvoids During Resin-Transfer Molding Process", Comp. Sci. \& Tech., 60, 2427-2434 (2000) DOI:10.1016/S0266-3538(00)00036-1

Karami, G. and Garnich, M., "Effective Moduli and Failure Considerations for Composites with Periodic Fiber Waviness", Comp. Struct., 67, 461-475 (2005) DOI:10.1016/j.compstruct.2004.02.005

Kas, Y. O. and Kaynak, C., "Ultrasonic (C-Scan) and Microscopic Evaluation of Resin Transfer Molded Epoxy Composite Plates", Polym. Testing, 24, 114-120 (2005) DOI:10.1016/j.polymertesting.2004.07.002

Kaynak, C., Akgul, E. and Isitman, N. A., "Effects of RTM Mold Temperature and Vacuum on the Mechanical Properties of Epoxy/Glass Fiber Composite Plates", J. Comp. Mat., 42, 1505-1521 (2008) DOI: $10.1177 / 0021998308092204$

Kedari, V. R., Farah, B. I. and Hsiao, K.-T., "Effects of Vacuum Pressure, Inlet Pressure, and Mold Temperature on the Void Content, Volume Fraction of Polyester/EGlass Fiber Composites Manufactured with VARTM Process", J. Comp. Mat., 45, 2727-2742 (2011) DOI: $10.1177 / 0021998311415442$

Khan, Z. M., Adams, D. O. and Anas, S., "The Influence of Multiple Nested Layer Waviness on the Compression Strength of Double Nested Wave Formations in a Carbon Fiber Composite Laminate", Mech. Comp. Mat., 51, 751760 (2016) DOI:10.1007/s11029-016-9546-7

Khoun, L. and Hubert, P., "Investigation of the Dimensional Stability of Carbon Epoxy Cylinders Manufactured by Resin Transfer Moulding”, Comp. A, 41, 116-124 (2010) DOI:10.1016/j.compositesa.2009.06.014

Khoun, L., de Oliveira, R., Michaud, V. and Hubert, P., "Investigation of Process-Induced Strains Development by Fibre Bragg Grating Sensors in Resin Transfer Moulded
Composites", Comp. A 42, 274-282

(2011) DOI:10.1016/j.compositesa.2010.11.013

Kugler, D. and Moon, T. J., "Identification of the Most Significant Processing Parameters on the Development of Fiber Waviness in Thin Laminates", J. Comp. Mat., 36, 1451-1479 (2002) DOI:10.1177/0021998302036012575

Kuentzer, N., Simacek, P., Advani, S. G. and Walsh, S., "Correlation of Void Distribution to VARTM Manufacturing Techniques", Compos. A, 38, 802-813 (2007) DOI:10.1016/j.compositesa.2006.08.005

LeBel, F., Fanaei, A. E., Ruiz, E. and Trochu, F., "Prediction of Optimal Flow Front Velocity to Minimize Void Formation in Dual Scale Fibrous Reinforcements", Int. J. Mat. Forming, 7, 93-116 (2014) DOI:10.1007/s12289012-1111-x

Leclerc, J. S. and Ruiz, E., "Porosity Reduction Using Optimized Flow Velocity in Resin Transfer Molding", $\begin{array}{llll}\text { Comp. A, 39, } & \text { 1859-1868 (2008) }\end{array}$ DOI:10.1016/j.compositesa.2008.09.008

Lee, D. H., Lee, W. I. and Kang, M. K., "Analysis and Minimization of Void Formation During Resin Transfer Molding Process", Comp. Sci. \& Tech., 66, 3281-3289 (2006) DOI:10.1016/j.compscitech.2005.07.008

Ledru, Y., Bernhart, G., Piquet, R., Schmidt, F., and Michel, L., "Coupled Visco-Mechanical and Diffusion Void Growth Modelling During Composite Curing", Comp. Sci. \& Tech., $\quad \mathbf{7 0}, \quad 2139-2145 \quad$ (2010) DOI:10.1016/j.compscitech.2010.08.013

Lawrence, J. M., Hsiao, K.-T., Don, R. C., Simacek, P., Estrada, G., Sozer, E. M., Stadtfeld, H. C. and Advani, S. G., "An Approach to Couple Mold Design and On-Line Control to Manufacture Complex Composite Parts by Resin Transfer Molding”, Comp. A, 33, 981-990 (2002) DOI:10.1016/S1359- 835X(02)00043-X

Li, Y., Stier, B., Bednarcyk, B., Simon, J.-W., Reese, S., “The Effect of Fiber Misalignment on the Homogenized Properties of Unidirectional Fiber Reinforced Composites”, Mech. Mat., 92, 261-274 (2016) DOI:10.1016/j.mechmat.2015.10.002

Lightfoot, J. S., Wisnom, M. R. and Potter, K. "Defects in Woven Preforms: Formation Mechanisms and the Effects of Laminate Design and Layup Protocol", Comp. A, 51, 99-107 (2013) DOI:10.1016/j.compositesa.2013.04.004

Loos, A. C. and Springer, G.S., "Curing of Epoxy Matrix Composites”, J. Comp. Mat., 17, 135-169 (1983) DOI:10.1177/002199838301700204

Lukaszewicz, D. H., Ward, C. and Potter, K., "The Engineering Aspects of Automated Prepreg Layup: History, Present and Future", Comp. B, 43, 997-1009 (2012) DOI:10.1016/j.compositesb.2011.12.003

Lundstrom, T. S., "Measurement of void collapse during resin Transfer Molding", Comp. A, 28, 201-214 (1997) DOI:10.1016/S1359-835X(96)00109-1

Lundstrom, S. and Gebart, R., "Influence from Process Parameters on Void Formation in Resin Transfer Molding”, Polym. Comp., 15, 25-33 (1994) DOI:10.1002/pc.750150105

Lundstrom, S., Gebart, R. and Lundemo, C. Y., "Void Formation in RTM" J. Reinf. Plast. \& Comp., 12, 13391349 (1993) DOI:10.1177/073168449301201207

Mahale, A. D., Prud'Homme, R. K. and Rebenfeld, L., "Quantitative Measurement of Voids Formed During Liquid Impregnation of Nonwoven Multifilament Glass Networks Using an Optical Visualization Technique", Polym. Eng. \& Sci., 32, 319-326 (1992) DOI:10.1002/pen.760320504

Manders, P. W. and Chou, T.-W., "Variability of Carbon and Glass Fibers, and the Strength of Aligned Composites", J. 
Reinf. Plas. \& Comp., 2, 43-59 (1983) DOI: $10.1177 / 073168448300200105$

Maurin, R., Davies, P., Baral, N., Baley, C., "Transverse Properties of Carbon Fibres by Nano-Indentation and Micromechanics", Appl. Comp. Mat., 15, 61-73 (2008) DOI:10.1007/s10443-008-9057-3

Matsuzaki, R., Seto, D., Todoroki, A. and Mizutani, Y., "Void formation in Geometry-Anisotropic Woven Fabrics in Resin Transfer Molding", Adv. Comp. Mat., 23, 99-114 (2014) DOI:10.1080/09243046.2013.832829

Mawardi, A. and Pitchumani, R., "Optimal Temperature and Current Cycles for Curing of Composites Using Embedded Resistive Heating Elements", J. Heat Transf., 125, 126-136 (2003) DOI:10.1115/1.1527903

Meink T. E., Huybrechts S., and Herman Shen M.-H., "Processing Induced Warpage of Filament Wound Composite Cylindrical Shells" J. Comp. Mat., 36, 10251047 (2002) DOI:10.1177/0021998302036009496

Mesogitis, T. S., Skordos, A.A. and Long, A.C., "Uncertainty in the Manufacturing of Fibrous Thermosetting Composites: A Review", Comp. A, 57, 67-75 (2014) DOI:10.1016/j.compositesa.2013.11.004

Michaud, D. J., Beris, A. N., Dhurjati, P. S., "Thick-sectioned RTM Composites Manufacturing, Part II. Robust Cure Cycle Optimization and Control", J. Comp. Mat., 36, 1201-1231 (2002) DOI:10.1177/0021998302036010589

Mizukami K., Mizutani, Y., Kimura, K., Sato, A., Todoroki, A. and Suzuki, Y., "Detection of In-Plane Fiber Waviness in Cross-Ply CFRP Laminates Using Layer Selectable Eddy Current Method", Comp. A, 82, 108-118 (2016) DOI:10.1016/j.compositesa.2015.11.040

Mogavero, J., Sun, J. Q. and Advani, S. G., "A Nonlinear Control Method for Resin Transfer Molding", Polym. Comp., 18, 412-417 (1997) DOI:10.1002/pc.10292

Mostafa, N. H., Ismarrubie, Z. N., Sapuan, S. M. and Sultan, M. T. H., "Fibre Prestressed Polymer-Matrix Composites: A Review", J. Comp. Mat., 51, 39-66 (2017) DOI: $10.1177 / 0021998316637906$

Mrse, A. M. and Piggott, M. R. "Compressive Properties of Unidirectional Carbon Fibre Laminates: II. The Effects of Unintentional and Intentional Fibre Misalignments", Comp. Sci. \& Tech., 46, 219-27 (1993) DOI: 10.1016/0266-3538(93)90156-B

Mukhopadhyay, S., Jones, M. I. and Hallett, S. R. "Tensile Failure of Laminates Containing an Embedded Wrinkle; Numerical and Experimental Study", Comp. A, 77, 219228 (2015) DOI:10.1016/j.compositesa.2015.07.007

Muric-Nesic, J., Compston, P., Noble, N. and Stachurski, Z. H., "Effect of Low Frequency Vibrations on Void Content in Composite Materials", Comp. A, 40, 548-551 (2009) DOI:10.1016/j.compositesa.2008.11.010

Naik, N. K., Sirisha, M. and Inani, A., "Permeability Characterization of Polymer Matrix Composites by RTM/VARTM", Progr. Aerosp. Sci., 65, 22-40 (2014) DOI:10.1016/j.paerosci.2013.09.002

Nawab, Y., Casari, P., Boyard, N., Sobotka, V. and Jacquemin, F., "In Situ Characterization of In-Plane Chemical Shrinkage of Thermoset Laminated Composites Using a Simple Setup", J. Reinf. Plast. \& Comp., 34, 931938 (2015) DOI: $10.1177 / 0731684415584634$

Nielsen, D. and Pitchumani, R., "Intelligent Model-Based Control of Preform Permeation in Liquid Composite Molding Processes, with Online Optimization", Comp. A, 32, 1789-1803 (2001) DOI:10.1016/S1359835X(01)00013-6

Nielsen, M. W., Schmidt, J. W., Hattel, J. H., Andersen, T. L. and Markussen, C. M., "In Situ Measurement Using FBGs of Process-Induced Strains During Curing of Thick
Glass/Epoxy Laminate Plate: Experimental Results and Numerical Modelling", Wind Energ., 16, 1241-1257 (2013)

Olave, M., Vanaerschot, A., Lomov, S. V. and Vandepitte, D. "Internal Geometry Variability of Two Woven Composites and Related Variability of the Stiffness", Polym. Comp., 33, 1335-1350 (2012) DOI:10.1002/pc.22260

Olivero, K. A., Barraza, H. J., O'Rear, E. A. and Altan M. C., "Effect of Injection Rate and Post-Fill Cure Pressure on Properties of Resin Transfer Molded Disks", J. Comp. Mat., 36, 2011-2028 (2002) DOI:10.1177/0021998302036016244

Olivero K. A., Hamidi, Y. K., Aktas, L. and Altan, M. C., "Effect of Preform Thickness and Volume Fraction on Injection Pressure and Mechanical Properties of Resin Transfer Molded Composites", J. Comp. Mat., 38, 937-958 (2004) DOI:10.1177/0021998304040562

Parlevliet, P. P, Bersee, H. E. N. and Beukers, A., "Residual Stresses in Thermoplastic Composites-A Study of the Literature. Part III: Effects of Thermal Residual Stresses", Comp. A, 38, 1581-1596 (2007) DOI:10.1016/j.compositesa.2006.07.002

Park, C. H. and Lee, W. I., "Modeling Void Formation and Unsaturated Flow in Liquid Composite Molding Processes: A Survey and Review", J. Reinf. Plast. \& Comp., $\quad 30, \quad 957-977 \quad$ (2011) DOI: $10.1177 / 0731684411411338$

Patel, N. and Lee, L. J., "Effects of Fiber Mat Architecture on Void Formation and Removal in Liquid Composite Molding”, Polym. Comp., 16, 386-399 (1995) DOI: $10.1002 / \mathrm{pc} .750160507$

Patel, N. and Lee, L. J., "Modeling of Void Formation and Removal in Liquid Composite Molding. Part II: Model Development and Implementation", Polym. Comp., 17, 104-114 (1996) DOI:10.1002/pc.10594

Patel, N., Rohatgi, V. and Lee, L. J., "Influence of Processing and Material Variables on Resin-Fiber Interface in Liquid Composite Molding”, Polym. Comp., 14, 161-172 (1993) DOI: $10.1002 / p c .750140210$

Pearce, N., Guild, F. and Summerscales, J., "A Study of the Effects of Convergent Flow Fronts on the Properties of Fibre Reinforced Composites Produced by RTM", Comp. A, 29, $141-152 \quad$ (1998) DOI:10.1016/S1359835X(97)00028-6

Potter, K., Khan, B., Wisnom, M., Bell, T. and Stevens, J., "Variability, Fibre Waviness and Misalignment in the Determination of the Properties of Composite Materials and Structures", Comp. A, 39, 1343-1354 (2008) DOI:10.1016/j.compositesa.2008.04.016

Rai, N. and Pitchumani, R., "Optimal Cure Cycle for the Fabrication of Thermosetting-Matrix Composites", Polym. Comp., 18, 566-581 (1997) DOI:10.1002/pc.10309

Rai, N. and Pitchumani, R., "Rapid Cure Simulation Using Artificial Neural Networks", Comp. A, 28, 847-859 (1997) DOI:10.1016/S1359-835X(97)00046-8

Rai, N. and Pitchumani, R., "Neural Network-Based Optimal Curing of Composite Materials", J. Mat. Process. \& Manuf. Sci., 6, 39-62 (1997)

Ravey, C., Ruiz, E. and Trochu, F., "Determination of the Optimal Impregnation Velocity in Resin Transfer Molding by Capillary Rise Experiments and Infrared Thermography”, Comp. Sci. \& Tech., 99, 96-102 (2014) DOI:10.1016/j.compscitech.2014.05.019

Requena, G., Fiedler, G., Seiser, B., Degischer, P., DiMichiel, M. and Buslaps, T., "3D-Quantification of the Distribution of Continuous Fibres in Unidirectionally Reinforced 
Composites", Comp. A, 40, 152-163

(2009) DOI:10.1016/j.compositesa.2008.10.014

Rohatgi, V., Patel, N. and Lee, L. J., "Experimental Investigation of Flow Induced Microvoids During Impregnation of Unidirectional Stitched Fiberglass Mat", Polym. Comp., 17, 161-170 (1996) DOI:10.1002/pc.10601

Rudd, C.D. Turner, M.R. Long, A.C. and Middleton, V., "Tow Placement Studies for Liquid Composite Moulding", Composites Part A, 30, 1105-1121 (1999) DOI:10.1016/S1359-835X(99)00010-X

Ruiz E. and Trochu, F., "Multi-Criteria Thermal Optimization in Liquid Composite Molding to Reduce Processing Stresses and Cycle Time", Comp. A, 37, 913-924 (2006) DOI:10.1016/j.compositesa.2005.06.010

Ruiz E. and Trochu, F., "Numerical Analysis of Cure Temperature and Internal Stresses in Thin and Thick RTM Parts", Comp. A, 36, 806-826 (2005) DOI:10.1016/j.compositesa.2004.10.021

Sas, H. S., Šimácek, P. and Advani, S. G., "A Methodology to Reduce Variability During Vacuum Infusion with Optimized Design of Distribution Media”, Comp. A, 78, 223-233 (2015) DOI:10.1016/j.compositesa.2015.08.011

Schell, J. S. U., Deleglise, M., Binetruy, C., Krawczak, P. and Ermanni P., "Numerical Prediction and Experimental Characterization of Meso-Scale-Voids in Liquid Composite Moulding", Comp. A, 38, 2460-2470 (2007) DOI:10.1016/j.compositesa.2007.08.005

Schmidt, C., Schultz, C., Weber, P. and Denkena, B., "Evaluation of Eddy Current Testing for Quality Assurance and Process Monitoring of Automated Fiber Placement”, Comp. B, 56, 109-116 (2014) DOI:10.1016/j.compositesb.2013.08.061

Scott, A. E., Sinclair, I., Spearing, S. M., Mavrogordato, M. N. and Hepples, W., "Influence of Voids on Damage Mechanisms in Carbon/Epoxy Composites Determined Via High Resolution Computed Tomography”, Comp. Sci. \& Tech., 90, 147-153 (2014) DOI:10.1016/j.compscitech.2013.11.004

Shih, C. -H., Liu, Q. and Lee, L. J., "Vacuum-Assisted Resin Transfer Molding Using Tackified Fiber Preforms", Polym. Comp., 22, 721-729 (2001) DOI:10.1002/pc.10574

Sozer, E. M., Bickerton, S. and Advani, S. G., "On-Line Strategic Control of Liquid Composite Mould Filling Process", Comp. A, 31, 1383-1394 (2000) DOI: $10.1016 / \mathrm{S} 1359-835 \mathrm{X}(00) 00060-9$

Sutcliffe, M. P. F., Lemanski, S. L. and Scott, A. E., "Measurement of Fibre Waviness in Industrial Composite Components", Comp. Sci. \& Tech., 72, 2016-2023 (2012) DOI:10.1016/j.compscitech.2012.09.001

Svanberg, J. M., "Prediction of Shape Distortions for a Curved Composite C-Spar”, J. Reinf. Plast. \& Comp., 24, 323-338 (2005) DOI:10.1177/0731684405043559

Swift, D. G., "Elastic Moduli of Fibrous Composites Containing Misaligned Fibres", J. Phys. D, 8, 223-240 (1975) DOI: $10.1088 / 0022-3727 / 8 / 3 / 006$

Timmerman, J. F., Hayes, B. S. and Seferis, J. C., "Cure Temperature Effects on Cryogenic Microcracking of Polymer Matrix Materials," Polym. Comp., 24, 132-139 (2003) DOI:10.1002/pc.10013

Tsukrov, I., Bayraktar, H., Giovinazzo, M., Goering, J., Gross, T., Fruscello, M. and Martinsson, L., "Finite Element Modeling to Predict Cure-Induced Microcracking in Three-Dimensional Woven Composites", Int. J. Fract., 172, 209-216 (2011) DOI:10.1007/s10704-011-9659-x

Vallons, K., Duque, I., Lomov, S.V. and Verpoest, I., "Loading Direction Dependence of the Tensile stiffness, Strength and Fatigue Life of Biaxial Carbon/Epoxy NCF
Composites", Comp. A, 42, 16-21 (2011) DOI:10.1016/j.compositesa.2010.09.009

Villière M., Guéroult, S., Sobotka, V., Boyard, N., Bréard, J. and Delaunay, D., "Dynamic Saturation Curve Measurement in Liquid Composite Molding by Heat Transfer Analysis", Comp. A, 69, 255-265 (2015) DOI:10.1016/j.compositesa.2014.11.024

Wang H. and Wang, Z.-W., "Statistical Analysis of Yarn Feature Parameters in C/Epoxy Plain-Weave Composite Using Micro CT with High-Resolution Lens-Coupled Detector", Appl. Comp. Mat., 23, 601-622 (2016) DOI:10.1007/s10443-016-9476-5

Wang J., Potter, K.D. and Etches, J., "Experimental Investigation and Characterisation Techniques of Compressive Fatigue Failure of Composites with Fibre Waviness at Ply Drops", Comp. Struct., 100, 398-403 (2013) DOI:10.1016/j.compstruct.2013.01.010

Wisnom, M. R., Reynolds, T. and Gwilliam, N., "Reduction in Interlaminar Shear Strength by Discrete and Distributed Voids", Comp. Sci. \& Tech., 56, 93-101 (1996) DOI:10.1016/0266-3538(95)00128-X

Woo, K. and Whitcomb, J. D., "Effects of Fiber Tow Misalignment on the Engineering Properties of Plain Weave Textile Composites", Comp. Struct., 31, 343-355 (1997) DOI:10.1016/S0263-8223(97)00025-1

Yang, J., Jia, Y., Ding, Y., He, H., Shi, T. and An, L., "Edge Effect in RTM Processes Under Constant Pressure Injection Conditions", J. Appl. Polym. Sci., 118, 10141019 (2010) DOI:10.1002/app.32470

Yurgartis, S. W. "Measurement of Small Angle Fiber Misalignments in Continuous Fiber Composites", Comp. Sci. \& Tech., 30, 279-293 (1987) DOI:10.1016/02663538(87)90016-9

Zhao, L., Cordovez, M. and Karbhari V. M., "Exothermic Temperature History in the Processing of Resin Infused Composite Structural Components", Appl. Comp. Mat., 8, 99-131 (2001) DOI:10.1023/A:1011232402628

Date received: February 15, 2017

Date accepted: June 21, 2017

Bibliography

DOI 10.3139/217.3444

Intern. Polymer Processing

XXXII (2017) 5; page 1-18

(c) Carl Hanser Verlag GmbH \& Co. KG

ISSN 0930-777X 